\title{
Performance and haematological parameters of Kano brown bucks fed diet containing graded levels of cottonseed cake
}

Finangwai, H. I., Orisakwe, C. J., Joshua, P., Udoh, E. D. and Dafur, B. S. Department of Agricultural Science, Federal College of Education, Pankshin Plateau State

\begin{tabular}{l} 
Corresponding Author:hoseafinangwai@gmail.com; 07038164366 \\
Abstract \\
\hline A 60 day study was carried out to determine the effect of protein supplement in Kano brown \\
bucks. Twenty four bucks with initial weight of $10.25-12.33 \mathrm{~kg}$ were grouped into three of \\
eight bucks each and were randomly assigned to the three treatment diets in a completely \\
randomized design. Prior to this, concentrate diets were formulated to contain $15 \%, 30 \%$ \\
and $45 \%$ cottonseed cake (CSC) as the protein supplement in the dietary treatments. Crop \\
residues formed the basal diet and were fed ad libitum. Alongside, fresh clean water was \\
provided to goats ad libitum. Parameters determined during the experiment were feed intake, \\
daily weight changes, Feed cost and and haematological parameters. Result showed that \\
protein, EE, lysine, methionine and fibre contents increased with increasing levels of CSC in \\
diet, whereas ME in kcal/kg reduced as CSC in diet increased. Feed intake significantly \\
(P<0.05) decreased with increasing levels of CSC in diet across treatment. Final weight \\
gain, average daily live weight and feed to gain ratio significantly (P<0.05) increased when \\
CSC in diet increased from $15 \%$ to $45 \%$. Feed cost (N/kg) increased with increased in CSC. \\
However, cost of concentrate intake and feed cost/gain were better for animal fed $45 \%$. \\
Although, varying levels of CSC in diet significantly (P<0.05) influenced the haematological \\
values of WBC, PVC and were within acceptable regions. The distribution of neutrophils, \\
lymptrocytes, monocytes, basophils and eosinophils reduced with increasing levels of CSC in \\
diet, though were not significantly (P>0.05) affected by variation of levels of CSC in diets. It \\
is concluded that including protein supplement such as cottonseed cake in buck diets at $45 \%$ \\
can be beneficial to Kano brown bucks.
\end{tabular}
Keywords: Feed Intake, Growth, Kano Brown and Hematological Parameters

\section{Introduction}

In Nigeria goats are kept as an important component of farming activities, particularly by small holder farmers. Goats had become an important aspect of animal production in Nigeria. Goats roam around and eat natural pastures and kitchen wastes which contain low crude protein (Aregheore, 2000). The low nutritional plane greatly hampers the productivity of these animals especially during the dry season when the crude protein content of the feedstuffs could be as low as $2 \%$ (Swat et al., 2004) leading to low growth rate, loss of body weight predisposition to disease.
The major constraint in improving the productivity of goats is their poor nutritional status. Low nutritional status of grass pasture and climate can alter the blood values of goat (Rodostits and Blood, 1994). Gramb et al. (2011) reported that hematological components are influenced by the quality and quality of feed.

Improvement in feed intake, digestibility of nutrients, weight gain and improved health status have been reported when concentrate supplements were fed to WAD goats (Arigbede et al., 2005). The aim of the research was to determine the effect of feeding graded levels cottonseed as protein 
supplement on performances and hematological components of Kano Brown Goats.

\section{Materials and methods \\ Location and site description}

The experiment was carried out at the demonstration farm of Agricultural Science Department, Federal College of Education Pankshin, Plateau state Nigeria. Pankshin is located at longitude $9^{\circ}$ and $26^{\circ}$ east and latitude $9^{\circ}$ and $10^{\circ}$ north of the Nigeria map. Pankshin has a milder climate than any part of the country but comparable only to that of the united state of America. The cold and dry wind of harmattan make the months of December and January cold and hazy. Pankshin has an average rainfall of $142 \mathrm{~cm}$. Pankshin local government area is rocky, landscape with cluster hills in most parts having undulating land. It has a tropical savannah vegetable with scattered forests. (Pankshin Local Government, 1999)

\section{Experimental animals and design}

Twenty four Kano brown bulks were obtained from Bashar cattle market of Wase Local Government Area of Plateau state. The goats (bucks) between 10.25 $12.33 \mathrm{~kg}$ weight were used. The goats were divided into three groups of eight each and were randomly allotted to the dietary treatments in a completely randomized design. The prior to the commencement of the experiment, the goats were drenched with oral anti-helminths. They were later subjected to a two weeks adjustment period after which record of performance considered.

\section{Experimental feeds and feeding}

Crop residues were collected after harvest from Pankshin environs and used as the basal feed. In addition to this a concentrate diet was formulated with cottonseed meal as the protein supplement. The level of cottonseed cake in diet varied from 15, 30 and $45 \%$ which formed the three dietary treatments respectively. Concentrate diet consisted of; ruminant premix, common salt, cotton seed cake, maize grain, maize offal, bone meal, lysine and methionine as shown in Table 1.

\section{Feeding period}

Feeding period was schedule two times daily (that is in the mornings and afternoons). Concentrate was fed $40 \%$ body weight, $60 \%$ body weight of roughages and water was given at $a d$ libitum. For each treatment left over were collected and weighed at daily bases. The adjustment period was 3 weeks. The roughages (soybean haulm were chopped into $4 \mathrm{~cm}$ length and offered to each treatment).

\section{Chemical analysis}

The percent Crude Protein (CP), Dry Matter (DM), Crude Fibre (CF), Ether Extract (EE) and ash content of ingredients and diets were analysed. The chemical analysis was carried out according to the AOAC (2000) procedure.

\section{Data and sample collection}

Data of feed intake, body weight gain and haematological parameters were collected. Daily feed intake was measured by subtracting the leftover from the total feed given to the bucks per head per day. Then, the calculated daily intake in each of the treatment used to determine live weight change and was done by the difference in weight from the previous week. The total body weight gain was determined at the end of the experiment by subtracting the initial body weigh in the first week from the final body weight in the last week of the experiment. Feed conversion ratio was calculated as the ratio of the feed intake to weight gain.

At the end of the experiment, blood sample was collected for three days and twice in 
each day (8:00am and 4:00pm) ) respectively. The bucks from each treatment were bled through the Jugular vein. The blood $(3 \mathrm{ml})$ was collected from each of the bucks and was transferred into a plastic sample bottle containing anti coagulated ethylene di-amine-tetra acetate (EDTA), to prevent the blood from clotting. The collection was done in the morning to avoid excess bleeding and stress on the goats. The haemotology analysis was performed according to Feldman et al., (2002) in order to determine the total white blood cell count (WBC), packed cell volume (PCV), and total differential leucocytes count (TLC and DLC), neutrophils, eosinophil, basophil, and monocyte.

\section{Data analysis}

Data collected were subjected to analysis of variance using the General Linear Model (GLM) procedure of statistical analysis system (SAS, 1998). Duncan Multiple Range Test (DMRT) was used to separate the means where significant differences existed (Duncan, 1955).

\section{Table 1: Ingredient composition of experimental diets}

\begin{tabular}{llll}
\hline \multirow{2}{*}{ Parameters } & \multicolumn{3}{l}{ Inclusion levels of CSC in diet (\%) } \\
\cline { 2 - 4 } & $\mathbf{1 5}$ & $\mathbf{3 0}$ & $\mathbf{4 5}$ \\
\hline Premix & 0.05 & 0.25 & 0.25 \\
Salt & 35 & 35 & 35 \\
Maize grain & 45 & 30 & 15 \\
Cotton seed cake & 15 & 35 & 45 \\
Methionine & 0.7 & 0.7 & 0.7 \\
Bone meal & 3.4 & 3.4 & 3.4 \\
Lysine & 0.4 & 0.4 & 0.4 \\
Total & 100 & 100 & 100 \\
\hline
\end{tabular}

$\mathrm{CSC}=$ Cottonseed cake; $\%=$ Percentage

\section{Results}

The chemical composition of diets is shown in Table 2. Result showed that increasing the level of cottonseed cake as protein supplement in the diet decreased their energy and ash content. Conversely, the crude protein and fibre, ether extract, lysine and methionine had a linear relationship with increased level of protein supplement in diet. The crude proteins in diet were between the ranges of 12.21-26.38 in reverse order. Surprisingly both calcium and phosphorus contents of diet remained unchanged as protein supplement varied from $15-45 \%$ in the diet.

The performance of Kano brown buck fed diet containing graded levels of cotton seed cake as protein supplement is shown in Table 3. Result indicated that initial live weights of the experimental goats in different dietary treatments did not vary significantly $(p>0.05)$. The final weight however, differed significantly $(\mathrm{p}>0.05)$ with goats fed $45 \%$ protein supplement in diet having the highest value of $17.17 \mathrm{~kg}$ while the lowest average final live weight value of $15.16 \mathrm{~kg}$ was recorded in those fed $15 \%$ protein supplement level in diet. Bucks fed 30\% protein supplement in diet were higher in final live weight gain though, not significantly $(\mathrm{p}>0.05)$ different from final weight of those on $15 \%$ protein supplement level in diet. 
Kano brown bucks fed diet containing graded levels of cottonseed cake

Table 2: The chemical composition of Diets containing graded levels of CSC

\begin{tabular}{llll}
\hline Feed ingredients & $\mathbf{1 5}$ & $\mathbf{3 0}$ & $\mathbf{4 5}$ \\
\hline Energy & 26.38 & 25.78 & 25.12 \\
Crude Protein & 12.21 & 14.16 & 16.11 \\
Crude Fiber & 9.87 & 12.5 & 15.12 \\
Ether extract & 3.08 & 3.74 & 4.40 \\
Ash & 0.82 & 0.7 & 0.58 \\
Calcium & 1.23 & 1.23 & 1.23 \\
Phosphorus & 0.67 & 0.67 & 0.67 \\
Lysine & 0.63 & 0.80 & 0.95 \\
Methionine & 0.83 & 0.89 & 0.95 \\
\hline
\end{tabular}

The live weight gain and average daily live weight gain maintained a similar pattern with the final live weight changes. Increasing the levels of cotton seed cake in diets as supplement of protein increased average daily live weight of animal significantly $(\mathrm{p}<0.05)$ with highest values recorded at $45 \%$ level of protein supplement. Average daily live weight at $15 \%$ and $30 \%$ were at $p a r(p>0.05)$. The dry matter intake of concentrate, roughage and total average daily intake were significantly $(\mathrm{p}<0.05)$ affected when protein supplement level in diet varied. Increasing the level of protein supplements in diet has a converse relationship with the concentrate intake across treatment .concentrate diet intake was highest $(p<0.05)$ at $15 \%$ and lowest $(p<0.05)$ at $45 \%$ protein supplement in diet.
Roughages intake followed the same pattern with animals on $15 \%$ significantly $(\mathrm{p}<0.05)$ highest in intake while those on $45 \%$ protein supplement in diet have lower $(\mathrm{p}<0.05)$ roughage intake.

The average daily intake was significantly $(\mathrm{p}<0.05)$ at $15 \%$ protein supplement level followed by average daily intake in animals on $30 \%$ protein supplement. The goats placed on $45 \%$ level of protein supplement in diet recorded a significantly $(\mathrm{p}<0.05)$ higher intake.

Feed to gain ratio is shown in Table 3. There was significant $(p<0.05)$ difference in the value of feed to gain ratio. Goats fed $45 \%$ protein supplement in diet benefited most from the feeding trial compared to the feed conversion efficiency values for goats fed 15 and $30 \%$ level of protein supplement which were though similar $(\mathrm{p}>0.05)$.

Table 3: Performance of Kano brown buck fed diet containing graded levels of Protein supplement

\begin{tabular}{llllll}
\hline & \multicolumn{2}{l}{ Inclusion levels of Cottonseed cake in diet (\%) } & & \\
\cline { 2 - 5 } Parameters & $\mathbf{1 5}$ & $\mathbf{3 0}$ & $\mathbf{4 5}$ & SEM & LOS \\
\hline Initial $(\mathrm{kg})$ & 12.00 & 12.00 & 12.33 & 7.50 & Ns \\
Final $(\mathrm{kg})$ & $15.16^{\mathrm{b}}$ & $15.17^{\mathrm{b}}$ & $17.17^{\mathrm{a}}$ & 0.74 & $*$ \\
Gain $(\mathrm{g})$ & $31.60^{\mathrm{b}}$ & $3.170^{\mathrm{b}}$ & $4.840^{\mathrm{a}}$ & 62.50 & $*$ \\
ADLW $(\mathrm{g} / \mathrm{h} / \mathrm{d})$ & $56.43^{\mathrm{b}}$ & $56.61^{\mathrm{b}}$ & $86.43^{\mathrm{a}}$ & 5.6 & $*$ \\
Roughage intake & $14,931.00$ & 13941.90 & 13105.26 & 168 & $*$ \\
Concentrate intake $\mathrm{g} / \mathrm{h} 9954.00^{\mathrm{a}}$ & $9,294.60^{\mathrm{b}}$ & $8736.84^{\mathrm{c}}$ & $168.00 *$ \\
Total intake g/h & $24,885.50^{\mathrm{a}}$ & $23236.50^{\mathrm{b}}$ & $21,842.1^{\mathrm{c}}$ & 224.00 & $*$ \\
ADI $(\mathrm{g} / \mathrm{h} / \mathrm{d})$ & $444.38^{\mathrm{a}}$ & $414.94^{\mathrm{b}}$ & $390.04^{\mathrm{c}}$ & 560 & $*$ \\
Feed to gain & $7.87^{\mathrm{a}}$ & $7.33^{\mathrm{a}}$ & $4.51^{\mathrm{b}}$ & 0.64 & $*$ \\
Cost of core intake(\#) 1233 & 1165.26 & 1108.44 & & \\
Cost/kg (\#kg) & 123.87 & 125.37 & 126.87 & & \\
Cost/ gain (\#/kg) & 390.19 & 376.59 & 229.02 & & \\
\hline
\end{tabular}

Values within the same row with at least one common letter as in Initial weight do not have signi ficant difference (P>0.05) while values within the same row with different supper script as in Final weight, Average daily live weight (ADLW), Gain, Total intake, Avrage daily intake (ADI), Feed to gain are significantly different $(\mathrm{P}>0.05)$. 
Table 4 : Haematology indices and serum metabolite of Kano brown buck fed diet containing various level of protein supplement

\begin{tabular}{llllll}
\hline & \multicolumn{3}{l}{ Inclusion level of diet (\%) } & & \\
\cline { 2 - 4 } Parameter & 15 & 30 & 45 & SEM & LOS \\
\hline WBC x $10^{6} / \mathrm{mm}^{3}$ & $36.00^{\mathrm{a}}$ & $17.10^{\mathrm{ab}}$ & $14.05^{\mathrm{b}}$ & 0.57 & $*$ \\
Packed cell volume (\%) & $45.00^{\mathrm{a}}$ & $35.60^{\mathrm{ab}}$ & $17.35^{\mathrm{b}}$ & 0.71 & $*$ \\
Lymphocyte & 52.50 & 50.50 & 45.50 & 1.69 & $\mathrm{~ns}$ \\
Neutrophils & 50.50 & 42.50 & 40.50 & 1.49 & $\mathrm{~ns}$ \\
Eosinophil & 4.00 & 4.00 & 0.00 & 0.18 & $\mathrm{~ns}$ \\
Basophil & 6.00 & 2.00 & 0.00 & 0.57 & $\mathrm{~ns}$ \\
Monocyte & 1.00 & 1.00 & 0.00 & 0.12 & $\mathrm{~ns}$ \\
\hline
\end{tabular}

Values within the same row with different supper script as in white blood cell $\left(\mathrm{X}_{10} / \mathrm{mm}^{3}\right)$, packed cell volume $(\%)$ are significantly different $(\mathrm{P}>\mathbf{0 . 0 5})$ while values within the same row with at least one common letter as in Lymphocyte, Neutrrophil, Eosinophil, Basophil, Monocytes do not have any significant difference $(\mathrm{P}>0.05)$.

The haematological parameter of Kano brown bucks fed diet containing graded level of cotton seed meal as protein supplement is shown in Table 4. Varying the level of protein supplement (PS) in diet significantly $(\mathrm{p}<0.05)$ influenced both white bold cell and packed cell volume. The distribution of WBC was inversely related. Increasing PS in buck diet reduced the value of WBC significantly $(\mathrm{p}<0.05)$ across treatment. The WBC vale were highest $(\mathrm{p}<0.05)$ at $15 \%$ PS at lowest $(\mathrm{p}<0.05)$ at $45 \%$ inclusion level of PS, however, WBC distribution at $30 \%$ an $45 \%$ were at parameter $(\mathrm{P}<0.05)$. Packed cell volume was highest $(\mathrm{P}<0.05)$ at $15 \%$ inclusion level of PS but it was similar ( $p>0.05)$ to the packed cell of bucks fed $30 \%$ of PS in diet at $45 \%$ PS level in diet packed cell volume were significantly reduced $(\mathrm{p}>0.05)$ though not significantly $(\mathrm{P}<0.05)$ different from packed cell volume of buck fed $30 \%$ PS.

Result showed the varying levels of PS in diet did not significantly $(\mathrm{P}<0.05)$ affect the distribution of neutrophils, lymphocytes, monocytes, basophils and eosinophls although their values reduced with increasing level of protein supplement in diet across treatment.

\section{Discussion}

The crude protein content of diet in this study responded correspondingly with increase in cottonseed cake in diet from $12.21-16.11 \%$ values in this study were higher than recommended value reported by ARC (1980) and NRC (1985) for optimum microbial gut activities. Gaterby (2002) suggested a crude protein range of $10-12 \%$ crude protein in diet is necessary for better ruminant productions. Even at this, the values obtained in the present study were higher than the suggested value for ruminants. The crude protein in the present study provided adequate nitrogen for the rumen microbes to maximally digest the dietary fibers thus producing adequate level of volatile fatty acid (Lamidi et al., 2010; Ibrahim et al., 2014). The energy value of diet in the study of $2512-2638 \mathrm{kcal} / \mathrm{kg}$ was within the range recommended by the NRC (1985) that increasing cotton seed cake in diet reduce the energy possible because of the lower ME of cottonseed cake. Cottonseed cake is reported to have 2070 $\mathrm{kcal} / \mathrm{kg}$ (Obioha, 1992), thus, increasing 


\section{Kano brown bucks fed diet containing graded levels of cottonseed cake}

each level in diet at the expense of maize (major source of energy) could have triggered this. However, since the energy was within the recommended range it means protein and energy ratio were enough to evaluate microbial activities. The slightly higher energy content of diet was to make room for accessibility problems due to the indigestible nature of some component of basal diet that were used as in this case, crop residues and the lignocellulosic component of underlinted and undecorticated nature of cottonseed.

Nutrient intake is the most important factor affecting animal performance (Mc Donald $e t$ al., 1995). The total dry matter intake reduced as cottonseed cake in diet increase. The reverse trend of intake in this study was not in agreement with result of Kolan (2004) that dry matter intake increase with concentrate supplement due to increase in protein supply and readily available energy to the rumen microbes which speed up digestion and create more spaces for intake (Jamie et al., 2009). The differences may be due to palatability differences when cottonseed cake levels changed in diet. The present study reveals that increasing protein and energy above the recommended $(12 \%$ crude protein) reduces intake. Another possible reason could be the taste, odour, colour, texture, and presence of antinutritional factor (gossypol contained in cottonseed).

Obioha (1992) reported a possible content of $1.1 \mathrm{mg} / \mathrm{kg}$ in undelinted and undecorticated cottonseed cake. The value of feed intake $(390.04-444.36 \mathrm{~g} / \mathrm{d})$ in the present study was higher than that of $100-200 \mathrm{~g} / \mathrm{h} / \mathrm{d}$ reported by Ibrahim et al., (2014) for Red Sokoto buck fed cottonseed cake. However, they were lower than $545.02-669 \mathrm{~g} / \mathrm{h} / \mathrm{d}$ reported by Ibrahim et al., (2014) when Sabara leaf meal was fed to Red Sokoto goat. The average daily intake in this study was comparable with $439.12-522.79 \mathrm{~g} / \mathrm{d}$ reported by Kolan
(2004) when small ruminants were fed graded level of sheanut cake in concentrate supplement to rice straw.

In the present experiment, the average daily live gain increases with increasing levels of cottonseed cake (protein supplement) inclusion in diet. This is possible due to increased supply to rumen microbes for effective utilization of the crop residues thereby making nutrient available for the bucks' absorption (Jamie et al., 2009).

The average daily live gain were $56.43 \mathrm{~g} / \mathrm{d}$, $56.61 \mathrm{~g} / \mathrm{d}$ and $86.43 \mathrm{~g} / \mathrm{d}$ for $15 \%, 30 \%$ and $45 \%$ inclusion levels of cottonseed cake in diet respectively. This shows that increasing cottonseed cake up to $45 \%$ did not lead to a decrease in weight gain, although dry matter intake increases when cottonseed cake level in diet were above $15 \%$. This disagrees with Issaka (2006) that decrease in feed intake result to decline also in gain of ruminants. The increased protein from $12-16 \%$ due to increasing levels of cottonseed cake could have been the possible reason.

The average daily gain values obtained in the present study are above the values reported by Hassan et al. (2016) of 20.22$44 \mathrm{~g} / \mathrm{h} / \mathrm{d}$ when lablab hay were included in the diet of Red Sokoto Goats, the value were close to the findings of Ibrahim et al. (2016) of 33.68-50.19g/h/d when Sabara leaf meal were fed to Red Sokoto goats. The results were comparable with the value of $55.95-64.23 \mathrm{~g} / \mathrm{h} / \mathrm{d}$ reported by Babale et al . (2005) when corn cobs replaced maize bran supplement with cowpea husks diet of Red Sokoto male goats.

The difference in growth rate value may be attributed to differences in nutrient composition of the basal diet offered (Mc Donald, et al., 1995). This is because the crop residues offered had less nutritive value in addition to its low digestible component compare to basal diet used in other studies. Breed difference could be 
another possible reason for differences in average daily gain value. It is worthy of note to say that weight gain in goats is highly dependent on protein and energy content of forage, (Ash and Norton, 1987). Warmington and Kirton (1990) suggested comparison of the productive potentials of goat's breeds is difficult because of the diversity of forages and supplements used in the wide range of production environments.

In the same vein, the feed to gain ratio had improvement when cottonseed cake level in diet increased beyond $15 \%$, with goats on diet with $45 \%$ inclusion level benefiting most. Decreasing intake in this case account for the better performance of bucks fed cottonseed cake. This is because daily gains in bucks were higher with increase in cottonseed cake levels. Thus, indicating a nutritionally balance diet at these levels. Salen et al. (2004) indicate that efficient utilization of nutrients that supply adequate energy protein is required for optimum growth performance in animals.

The values of feed to gain ratio of 4.51-7.87 in this study are comparable with 7.2610.22 reported by Babale et al. (2015). However, they were far lower than 13.1318.17 reported by Ibrahim et al. (2014) and 10.72-24.90 reported by Hassan et al. (2016) for Red Sokoto and Kano brown bucks.

The significant difference in the values of lymphocytes in this study disagree with the report of Kolan (2010) when fed graded levels of shear butter nut cake that diet did not affect white blood cell significantly. Barden et al. (2007) reported similar findings in sheep and goats fed cassava peal. The lymphocytes distributions were lower than the $5 \times 10^{6} / \mathrm{dl}-11 \times 10^{6} / \mathrm{dl}$ reported by Scott et al. (2006). Although cottonseed cake influenced white blood cell significantly Thorp et al. (1991) have reported a normal range for sheep white blood cell count of $60-65 \%$. The lower level of white blood cell below the normal range is an indication that no foreign organism was introduced into the blood that would have made the white blood cells counts to increase in order to fight against their evasion in the animal body ( Egbe-Nwiye $e t$ al., 2007).

The non significant difference in lymphocytes distribution disagrees with Barden et al. (2007) but agrees with Kolan (2010). The lymphocytes normal ranged have been reported to be $60-65 \%$ (Thorp et al., 19991). The values of $55-52.50$ were close to the normal range. High lymphocyte count above the normal range is a response of the body to virus, bacterial or parasite infection (Kolan, 2010). This indicates that inclusion level of cottonseed cake in bucks' diet did not introduce any infection into the animal body or expose the animal to infectious organism.

Differential neutrophils values were not significantly affected by varying level of cottonseed cake in diet. The values were between $40.50-50.50 \%$. These values were similar to report by Kolan (2010) that, increasing level of protein supplement do not affect percentage neutrophil. Granulocyte count prevents potential inflammatory process (Naskalski et al., 2007). Eosinophils count was significantly affected by diet. The value was between $0.00-4.00 \%$ although count reduced as cottonseed cake in feed was increasing. Eosiniphils number increases in the blood stream in the presence of allergen or parasites in the animal's body (David, 2005). Basophil were insignificantly affected by varying levels of cottonseed cake in diet of bucks. It maintains the pattern with eosinophil reducing with increasing levels of cottonseed cake in diet. The non significant difference of basophils percentage in the white blood cell across treatment agrees with the report of Kolan 
(2010) and falls within the normal range of small ruminant (Baud, 2008). Varying cotton seed cake in diet did not affect the monocyte count in the lymphocytes across treatment, although there was slight reduction with increasing level of cotton in diet. The similarities in the monocyte count across treatment indicate that the inclusion of cottonseed did not introduce any harmful organisms in the body of bucks nor increase death body cells that warrant removal. The significant difference in packed cell volume of buck fed cottonseed of variable levels disagreed with the report of Kolan (2010) when West African dwarf sheep fed cassava pulp and sheanut cake respectively.

\section{Conclusion}

Feeding diets containing graded levels of CSC as protein supplement in Kano brown Buck led to improved growth performance of the Buck as CSC above 15\% depressed intake in Buck. Inclusion of CSC in Buck diet at $45 \%$ improved feed to gain ration with no negative haemotological effect in the blood of goats

\section{Recommendation}

Small holder farmers in Nigeria should incorporate CSC in concentrate diets of Bucks at $45 \%$ as a way of improving live weight gain, nutrient utilization and minimizing cost of production.

\section{References}

AOAC. 2000. Official Method of Analysis. Vol. 1. 17 $7^{\text {th }} \mathrm{Ed}$. Association of Official Analytical Chemists, Arlington, VA.

Arnold, G. W., Deboer, E. S. and Bound, C. A. P. 1980. The influence of odour And taste on food preferences and food intake on sheep. Australian Journal of Agric. Res. 31, 571-578.

Calhoun 1990. Increase erythrocyte fragility in cattle, sheep and goats Fed cotton seed pg 30 in sheep and goat.
Texas experimental station College stage

Coles, E. H. 1980. Veterinary Clinical pathology, $3^{\text {rd }}$ Ed. W.B. Sandets one. CO, Philadelphia, pp. 10-20.

Devendra, C. and Burns, M. 1970. Goat Production in the tropics. Technical Communication. No.1 of the Common Wealth Bureau of Animal Breeding Genetics. Edinburgh. UK. 1970:1-25.

Duncan, D. B. 1995. Multiple F test. Biometrics, 11:1-42.

Egbe-Nwiye, T. N., Nwaosu, S. C. and Salami, H. A. 2000. Hematological Values of apparently healthy sheep and goat as influenced by age and Sex in arid zone of Nigeria. African Journal. Biomed. Res., 3: 109-115.

Ekpa, G. N., Suleiman, I. O. and Ahaphonsus, C. 2011. Effect of age, hair type and Body condition score on body conformation traits in Yankasa rms. Nigeria Animal Science, 13:2328.

Esonu, B. O., Emenalom, O. O., Ododibie, A. B. I., Herbbert, U., Ekpor, C. F., Okoli, I. C. and Ihuekwumere，F. C. 2000 . Performance and blood Chemistry of weaned pies fed raw mucuna beans (Velvet bean) meal. Tropical Animal production, 4:49-54.

Farinu, G. O., Ojebiyi, O. O., Akinlade, J. A. and Laogun, T. A. O. 2005. Effect Of graded level of wild sunflower meal on performance of pullet Chicks and growing pullets Pp.217-219 in proc. $10^{\text {th }}$ Ann . Conf. Anim. Sci. Assoc. Nigeria, Ado Ekiti Univ. Ekiti, Nigeria.

Gramb, M., Uchechi, I. J., Kehinde, A. N., Bala, A. S. and Onimis, R. A. 2011. Hematological and serum biochemical indices of growing rabbits fed Camel blood rumen 
content mixture. Journal Roavs. 1(N), 44-47.

Holman, H. H. and Dew, S. M. 1963. The blood picture of the goat I. The two year old female goat. Res. Vet. Sci., 4:124-130.

Iheukwumere, F. C., Okoli, J. C., Anyanwu, G. A. and Esonu, B. O. 2005. Growth performance, hematology and serum biochemical Constituents of grower rabbit fed Microdesmispuberula, HooksEuphorbia Ceae. Animal Production Research Advances, 1:24-31.

Jimenz, H. H. 1989. In Reproduction and breeding techniques for Laboratory animals'. E. S . E Herfesedlphiladephia, Lea and Febiger,.

John and Debrah, S, 2010. Forage Research in Small holder and pastoral Production Systems. FAO Corporate Document Repository.

Millson, G. C., West, L. D. and Dew, S. M. 1960..Biochemical and hemotoLogical observation on the blood and cerebra-spinal fluid of Chemically healthy and scrappier affected goats. T. Comp. path. 70:194-198.

Morgan, B. M. 1989. Nutritional values and anti-nutritional component of whole And extracted moringaolifera leaves. Animal feed science and Technology, 63, 211-228.

NRC, 2007. Nutrient requirement of small ruminants: sheep, goats, Cervids, and new world camelids. Nutritional Academy press, $384 \mathrm{p}$.

Odeyinka, S. M. and Okanade,. G. K. 2005. Goat production in Oyo state: A case Study of Ogbomosho town. Nig. J. Anim Prod.:32 (1):108-115.

Olayimi, F .O., Farotimi, J. O. and Fagohum, O. A. 2000. Hematology of West African Dwarf sheep under two different management systems in
Nigeria. African Journal of biomedical Research. 3:197-198.

Otchere, E. O., Dadzie, C. B. M., Erbyn, K. G. and Ayebo, D. A. 1977. Response of sheep on rice straw or cassava peel fortified with urea Molasses as feed to grazing sheep. Ghana Journal of Agric. sci., 10:6166.

Pampori, Z. A. 2003. Field cum Laboratory Procedure in animal health Care. DIVP publishing house, New Delhi, India, PP 172-182.

Radostits, O. M. and Blood, D. C. 1994. Veterinary Medicine. BailliereTindall, London. Review by Dyfed Lloyd Evans.

Robert, K. M., Darvl, K. G., Peter, A. M. and Vector, W. R. 2000. $V$. Biochemistry. $25^{\text {th }}$ Edn. McGrow Hill. New York. PP.763-765.

SAS Institute. 1998. SAS/STAT Software, Release 6.03. SAS institute, Inc., Cary, NC.

Schalm, O. W., Jain, N. C. and Card, C. I. 1975. Veterinary hematology, $3^{\text {rd }} \mathrm{Edn}$. Lea and Fibinger, Philadelphia, PP.144-167.

Tambuwal, F. M., Agale, B. M. and Bangana, A. 2002. Hematology and Biochemical values of apparently healthy Red Sokoto goats. Proc. $27^{\text {th }}$ Annual Conference Nigeria Society of Animal Production (NSAP), 17-21 march, (2002), FUTA, Akure, Nigeria. PP.55-53.

Zahid, R. T., Hartman, P. K. and Howards, S. 2003. Reproductive performance of African indigenous small ruminants under various management Systems. Anim Reprod Sci, 20, 211-228.

Received: $4^{\text {th }}$ November, 2017 Accepted: $20^{\text {th }}$ February, 2018 